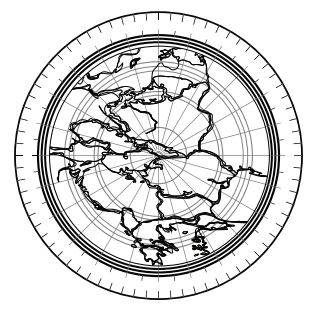

\title{
The European Tale of Downfall (and Survival)
}

DOI: https://doi.org/10.11649/sn.2525

\author{
Agnieszka Sadecka \\ Jagiellonian University in Kraków \\ https://orcid.org/0000-0002-5964-7058 \\ e-mail: agnieszka.sadecka@uj.edu.pl
}

\begin{abstract}
This article is a review of the book After Europe by Ivan Krastev. It focuses on the author's claims regarding the crisis in which Europe finds itself and questions some of the historical parallels likening the current period to various disintegration moments in the past. The review also addresses Krastev's observations concerning contemporary European challenges, particularly the migration crisis and the rise of populism. While many of Krastev's arguments are convincing, the review posits that in spite of some worrying phenomena, there are also grounds for cautious optimism.
\end{abstract}

Keywords: Europe; European Union; disintegration; European identity; populism

The second decade of the twenty-first century, marked by crises, tensions and the emergence of populist leaders, brings to mind the tumultuous years of a century ago, which eventually led to two world wars. Ivan Krastev, political scientist and commentator, chairman of the Centre for Liberal Strategies and fellow of the Institute of

This work was supported by the Polish Ministry of Education and Science.

No competing interests have been declared.

Publisher: Institute of Slavic Studies, Polish Academy of Sciences.

This is an Open Access article distributed under the terms of the Creative Commons Attribution 3.0 PL License (creativecommons.org/licenses/by/3.0/pl/), which permits redistribution, commercial and non-commercial, provided that the article is properly cited. (c) The Author 2021. 
Human Sciences (IWM), seems partial to such historical parallels. In his 2017 essay After Europe, Krastev admits to having a déjà-vu. The collapse of the Habsburg Empire arrived in a rather unexpected fashion in 1917, bringing to an end the idea of a multi-ethnic, largely liberal empire (at least in its final years), which makes us wonder whether we are experiencing "a similar 'disintegration moment' in Europe today" (Krastev, 2017, p. 2). Krastev opens his analysis with a provocative question: "[i]s the European Union doomed to fall apart in the fashion of the Habsburg Empire? Is 2017 - marked by critical elections in the Netherlands, France, and Germany - fated to be as momentous a year as 1917?" (Krastev, 2017, p. 3).

At the start of 2021, we already know that this was not the case. Krastev's pessimistic predictions were not fulfilled, at least not immediately. The 2017 elections in France, the Netherlands and Germany, feared by Krastev, did not bring an outcome that would destroy the Union. Marine Le Pen lost to the decidedly pro-European Emmanuel Macron, who obtained twice as many votes as his opponent. ${ }^{1}$ The liberal VVD headed by Mark Rutte won the Dutch parliamentary elections, leaving Geert Wilders' anti-immigration party significantly behind. ${ }^{2}$ As for Germany, the populist Alternative für Deutschland (AfD) had grown in strength (12.6\% in 2017, while in 2013 it obtained 4.7\%), but it came third, after CDU/CSU (26.8\%) and SPD (20.5\%). The long-drawn Brexit saga appears to be more of a deterrent than an encouragement for other member states to leave the EU. The geopolitical situation has changed as well: in 2020 , Donald Trump lost power in the United States to Joe Biden and Kamala Harris duo, firmly committed to a liberal agenda. And finally, the Covid-19 pandemic has shaken the European social, political and economic reality. European societies may come out of this latest crisis wounded and traumatized, which may lead to further tensions and divisions, but it may also be an opportunity for new impetus in EU integration. Thus, neither the year 2017 nor the following years have caused the downfall of the European Union, although the problems that Krastev outlines in his work are far from being solved.

In his compelling and thought-provoking work, Krastev provides multiple examples of how European integration lost its appeal and "what once kept the union together no longer holds" (Krastev, 2017, p. 5). Not only has Europe lost its centrality in the world, its confidence and its ability to deal with the "real world" (Krastev, 2017, p. 8), but it is also becoming "autistic" (Krastev, 2017, p. 7) and suffers from an "identity crisis" (Krastev, 2017, p. 9). There are several reasons for this loss of a common frame of reference, in Krastev's opinion. The young generation is no longer traumatized by the legacy of the Second World War (ergo, the importance of European integration as a guarantee of peace may no lon-

1 In the second round of 2017 presidential elections in France, Emmanuel Macron received $66.10 \%$ of votes, while Marine Le Pen only 33.90\%. See: Résultats de l'élection présidentielle 2017, n.d.

2 VVD (Volkspartij voor Vrijheid en Democratie - People's Party for Freedom and Democracy) came first as it obtained 21.3\% of votes, while Wilders' Party of Freedom (Partij voor de Vrijheid - PVV) came second at 13.1\%. See: Netherlands - 2021 general election, n.d. 
ger be evident), there is no common geopolitical goal since the Soviet Union is gone and attitudes towards Russia are ambivalent, the welfare state model is under question, and postmodernism, post-nationalism and secularism no longer appear as innovative ideas that could inspire other global actors (Krastev, 2017, pp. 5-9). This diagnosis ushers in a prediction that Europe's future is not as optimistic as many commentators once hoped (Fukuyama, 1989; Leonard, 2005; Rifkin, 2004). Krastev believes that "the disintegration train has left Brussels's station" (Krastev, 2017, p. 10), and the consequences of that will not necessarily be war or violent conflict, but certainly what is ahead of the continent is disarray and turmoil (Krastev, 2017, p. 10). While "[p]olitical, cultural, and economic cooperation won't evaporate, [...] the dream of a Europe free and united probably will" (Krastev, 2017, p. 10), concludes the author.

Even though Krastev paints a bleak picture for Europe's future, he underlines that his goal is "neither to save the EU nor to mourn it", and that it is "by no means the book of a Euroskeptic" (Krastev, 2017, p. 11). His intention is rather to wake Europeans from slumber and inertia with his provocative hypothesis, in order to prevent disintegration looming on the horizon. Krastev not only makes a historical parallel with the dismantling of the Habsburg Empire: his déjà vu also involves his personal memory of the collapse of the Soviet Union. He seems to suggest that Eastern Europeans, having a first-hand experience of the end of a certain political entity, are more attuned to signs of disintegration.

The experience of the sudden and nonviolent end of something that we were confident was permanent (until it was no more) is the defining experience in the life of my generation. We were overwhelmed by the opportunities that were suddenly opened up and the newly discovered sense of personal freedom. But we were struck as well by the newly discovered sense of the fragility of all things political. (Krastev, 2017, p. 12)

In this quote, Krastev paraphrases Alexei Yurchak's 2005 work on the last Soviet generation, entitled Everything Was Forever, Until It Was No More, which provides an in-depth analysis and interpretation of the late Soviet cultural condition. While the early 1990s may have taught Eastern Europeans something about instability and change, their experience is not entirely comparable to that of the former citizens of the Soviet Union, and may not serve as a lesson in preventing the disintegration of a very unique political entity that is the European Union. Furthermore, Eastern Europeans, for centuries suffering from conflict and instability, are afflicted by the opposite problem of the one attributed to Westerners: a sense of fatalism. It is precisely that "sense of the fragility of all things political" (Krastev, 2017, p. 12), mentioned by Krastev, that leads to low trust in institutions and scepticism about the longevity of any political project. Thus, what Krastev presents as Eastern Europeans' forte may also be a handicap. Perhaps his own rather pessimistic assessment of the future of European integration is also tainted by the same fatalism.

Krastev identifies two main examples of problems that provoke a deep crisis and may potentially break up the European Union: the so-called refugee crises and the rise 
of illiberal, populist parties with an anti-pluralist, anti-meritocratic agenda in multiple EU member states. According to the author, these two challenges are interrelated. He writes: "These anxious majorities fear that foreigners are taking over their countries and jeopardizing their way of life, and they are convinced that the current crisis is brought on by a conspiracy between cosmopolitan-minded elites and tribal-minded immigrants" (Krastev, 2017, pp. 14-15). It appears from Krastev's analysis that the threat comes from two groups: those who are culturally foreign, and those who are ideologically, or even morally, foreign. This binary construct deepens the sense of the difference between the notions of "Us" and "Them" and contrasts the "pure people" against the "corrupt elites" - if we use the language of populism (Mudde, 2004) - or those from Somewhere and those from Anywhere, in the words of David Goodhart, quoted by Krastev (Krastev, 2017, p. 34).

Indeed, the refugee crisis has revealed that Europeans were not prepared for the process that was foretold by scholars of migration for a few decades now (Castles, 1998; De Haas, 2008; Stalker, 2002; Triandafyllidou, 2016). According to Krastev, this crisis is a gamechanger, it is - in his words - Europe's 9/11 (Krastev, 2017, p. 19). While such comparison may seem somewhat too strong, especially in light of the subsequent Covid-19 crisis, which affected individual Europeans even more than the refugee crisis, Krastev is right in focusing on the refugee crisis to explain a range of problems. True, the refugee crisis put many of the purportedly common European values in question. It has shown a lack of solidarity among the member states and a lack of compassion among some of the EU citizens. It has eroded the global legitimacy of Europe as a champion of human rights. It showed that long-term and large-scale processes, such as decolonization and globalization, will inevitably lead to international migrations in search of a better life, since that better life may now be only a plane or boat journey away. At the same time, those native Europeans whose quality of life may either already be not very high or comes under real or imagined threat have nowhere else to go. As Krastev points out,

[i]n the tortured imagination of Europe's threatened majorities, immigration is a form of invasion, with outsiders arriving from all directions, and exit for the natives is not an option. In this sense, far-right voters perceive themselves as [...] tragic figures [...] because they have no place to return to. (Krastev, 2017, p. 28)

Krastev puts a finger here on two seemingly separate phenomena, which are actually superimposed on one another: the global inequalities of resources, power and prestige, and the internal inequalities among the societies of the so-called First World. A white, middle-aged American Trump supporter may appear to be a rich man to someone fleeing hunger in Sub-Saharan Africa or war in Syria, but that same man may feel like someone at the bottom of the ladder in his own society (or as a stranger in his own land, using Arlie Hochschild's metaphor; Hochschild, 2018). Similarly, in the European context, an elderly unemployed ex-factory worker in Bulgaria, who has trouble making ends meet, may have difficulty understanding why a young, educated, middle-class 
Afghan, with a new smartphone, should be provided with assistance from European taxpayers' money. The inability to feel compassion and the revolt against tolerance and inclusiveness as a shared value are yet another manifestation of the crisis of values that Krastev discusses in his book.

While the importance of the refugee crisis and its manifold consequences is undeniable and rather well-understood by the European public, Krastev brings something new to the discussion by linking the migration crisis to the crisis of liberalism in Europe. In his opinion, "[t]he inability and unwillingness of liberal elites to discuss migration and contend with its consequences [...] are what make liberalism for so many synonymous with hypocrisy. This revolt against the hypocrisy of liberal elites is fundamentally reshaping Europe's political landscape" (Krastev, 2017, p. 25). The already existent distrust of liberal elites and disillusionment with the EU project, the lack of true engagement among the young pro-European generation, the crisis of the Left in most European countries, the disappearance of the internationally-minded working class, the crisis of the discourse of human rights in general - all these phenomena, in Krastev's view, contribute to a grave crisis of liberalism in Europe. This crisis provides fertile ground for populist actors who exploit the uncertainty of the future, the ontological insecurity, the fear of change and the lack of trust in leaders and institutions in order to gain power. It is particularly visible in Eastern Europe, where populist political parties managed to gain significant power, and to move from illiberal rhetoric to the implementation of the illiberal, or even (semi-) authoritarian agenda (Bustikova \& Guasti, 2017; Fomina \& Kucharczyk, 2016; LendvaiBainton \& Szelewa, 2020; Markowski, 2019; Sadurski, 2019). The threat of the arrival of migrants gave fuel to cynical populist politicians, like Jarosław Kaczyński and Viktor Orbán, who used it to stoke fear and build support around their nativist, xenophobic and often Eurosceptic agendas. As a result, old divisions are awakened, and European solidarity is challenged. In Krastev's words, "migration has brought a renationalization of politics and a concomitant resurrection of the East-West divide, if indeed it ever really disappeared" (Krastev, 2017, p. 44).

While it would be difficult to disagree with Krastev on the diagnosis above, given how the European conflict on refugee quotas unfolded, his characterization of Eastern Europeans tends to be overly generalized. Certainly, the anti-refugee attitudes in Eastern Europe were by and large more pronounced than in its Western part, but let us not forget the importance of the anti-immigrant agenda in the United Kingdom (especially visible during the Brexit campaign), in France or in the Netherlands - to mention just a few examples. Xenophobia in Poland or Hungary may be based on a more ethnonationalist discourse than the one observed in Western Europe. However, it seems that it is not displayed equally in all of Eastern Europe, and certainly not among the entire society of each of the member states. In fact, it is now clearly visible that attitudes towards refugees are affected by political discourse: before the mediatization and politicization of the migration crisis (Krzyżanowski, 2018), 72\% of Poles surveyed by CBOS were supportive of accepting refugees from conflict zones, while in February 2016 this 
percentage went down to an all-time low of $39 \% .^{3}$ This shows that the right-wing politicians' strategy of spreading panic was effective, even though it now starts to appear short-lived. Recently, the attitudes towards refugees became more positive: according to the survey by Kantar for UNHCR, 77\% of respondents thought that Poland should accept refugees from war zones or those who were victims of persecutions. ${ }^{4}$ Certainly, the reasons why Eastern Europeans fear the influx of refugees and are reluctant to keep the external EU borders open are manifold, and Krastev rightly identifies many of them. A demographic panic, especially among the smaller nations, is one reason - as young people leave to larger cities or abroad, one can observe a gradual emptying of many post-socialist regions (Dzenovska, 2020). If this void is filled by people representing different cultures, speaking different languages and observing different traditions, the more conservative parts of the Eastern European societies will fear a gradual decay of the local culture, already threatened by the globalized, postmodern and cosmopolitan world. Krastev mentions such resentment of cosmopolitanism as yet another sign of the rift between East and West (Krastev, 2017, pp. 47, 55).

However, we can observe that the support towards the EU remains high in Eastern Europe, particularly in Poland (European Commission, 2021; for Poland see also: Centrum Badania Opinii Społecznej, 2019). A growing number of young Poles embrace Europeanness and cosmopolitanism (Moes, 2009). Generations born in the 1980s and onwards do not clearly remember the socialist times and the period of transition. Their experience was linked to Europe from an early age and led to not only a cultural identification, but also to an emotional one (Moes, 2009). Many remember holidays in Italy, school exchanges with Germany or a semester in Belgium at an Erasmus scholarship. ${ }^{5}$ Obviously, this is not the case for the entire Polish society and is more commonly observed among the urban middle class, but there is a growing group of people, in each of the "new" Eastern European member states, for whom Europe is a lived reality (Mazzoni et al., 2018; Moes, 2009; Van Mol, 2018). Undoubtedly, the emergence of true European demos is still far away, and political apathy, lack of civic engagement and Euroscepticism remain problems to be solved. Still, these are problems that occur in all European societies, not only in the Eastern European member states.

Indeed, there is a gap between the Somewheres - people with a strong attachment to one place, to tradition and to nation and opposed to change - and Anywheres, characterized by a global outlook and "convertible competencies" (Krastev, 2017, p. 89), who may leave any time and lead their life anywhere. Nevertheless, calling it after Krastev a conflict between the dispossessed and the no-loyalty elites would be exactly what the populists want. Firstly, the open-minded, the pro-European, the liberal are not a tiny elite - they constitute a large

\footnotetext{
3 See CBOS Reports from 2015 and 2016 respectively: Centrum Badania Opinii Społecznej, 2015, 2016.

4 See Kantar Report for UNHCR from 2021 (Kantar, 2021)

5 For example, in the two decades of Polish participation in the Erasmus programme, more than 200,000 university students took part in it, as did 100,000 technical and vocational school students. In total, already ten million Europeans (including Eastern Europeans) have participated in the programme (European Commission, 2020). For an academic discussion on the impact of cross-European mobility on the formation of a European identity among young people, see Mazzoni et al., 2018; Moes, 2009; Van Mol, 2018.
} 
part of the society (judging by election results and opinion polls, sometimes a third or even half of the society, depending on the country), whose political representatives have simply lost to the populist right for a number of reasons. Assuming that the illiberal turn will not last forever, the coming to power of more pro-European, liberal forces in at least some of the Eastern European EU member states could mean that European integration would get a new boost, contrarily to the pessimistic view of Krastev. Secondly, the liberal, urban, educated middle class may have convertible competencies, but this does not exclude their attachment to their country, city and local culture. The emergence of various progressive urban movements and their entry into politics could be a case in point here (Kubicki, 2020; Pluciński, 2014). ${ }^{6}$ Finally, while a strong politicization of public discourse can be observed, there is a number of issues where consensus can be found and the perceived differences can be breached - let us not forget that many of them are artificially and cynically emphasized by political actors for their own political gain.' If, as Krastev writes, populists promise to their voters loyalty, sacrifice and intimacy (Krastev, 2017, p. 92), liberal political leaders could learn to combine their meritocratic vision of society with a more compassionate, empathetic approach. The Covid-19 crisis is certainly a time that puts these very qualities to test, and it challenges the resilience of European societies. The pandemic has provided us with examples of the union's fragility (closing of internal EU borders, scramble for medical resources and equipment, lack of unified response), but at the same time it has shown Europe's strength in singular acts of solidarity, in joint vaccine purchases, and in the planned recovery package for the entire EU. Thus, Europeans and the project of EU integration still find themselves in Perhapsburg - using Krastev's term (Krastev, 2017, p. 107) - and their future is uncertain. Nevertheless, Europe is not dead yet, it may once again recover from crisis, and the title of Krastev's book may prove to be premature.

\section{References}

Bustikova, L., \& Guasti, P. (2017). The illiberal turn or swerve in Central Europe? Politics and Governance, 5(4), 166-176. https://doi.org/10.17645/pag.v5i4.1156

Castles, S. (1998). The age of migration: International population movements in the modern world. Macmillan International Higher Education. https://doi.org/10.1007/978-1-349-26846-7

Centrum Badania Opinii Społecznej. (2015). Polacy wobec problemu uchodźstwa. Komunikat z Badań CBOS, 2015(81). https://www.cbos.pl/SPISKOM.POL/2015/K_081_15.PDF Centrum Badania Opinii Społecznej. (2016). Stosunek Polaków do przyjmowania uchodźców. Komunikat z Badań, 2016(24). https://www.cbos.pl/SPISKOM.POL/2016/K_024_16.PDF

\footnotetext{
6 In the last few years, activists from such movements, for instance in Warsaw, Budapest and Bucharest, managed to enter politics, either as parliamentarians or city mayors.

7 Such common ground could be found, for instance, in various discussions on healthcare and education, solutions for ageing societies, protection of the environment and biodiversity, or on supporting technological development and innovation. Of course, each issue can be politicized, but perhaps there is some potential to breach differences among the more moderate members of the opposite political camps.
} 
Centrum Badania Opinii Społecznej. (2019). 15 lat członkostwa Polski w Unii Europejskiej. Komunikat z Badań, 2019(59). https://cbos.pl/SPISKOM.POL/2019/K_059_19.PDF

De Haas, H. (2008). The myth of invasion: The inconvenient realities of African migration to Europe. Third World Quarterly, 29(7), 1305-1322. https://doi.org/10.1080 /01436590802386435

Dzenovska, D. (2020). Emptiness: Capitalism without people in the Latvian countryside. American Ethnologist, 47(1), 10-26. https://doi.org/10.1111/amet.12867

European Commission. (2020). 10 million Erasmus participants and counting. https://ec.europa. eu/commission/presscorner/detail/en/qanda_20_130

European Commission. (2021). Public opinion in the European Union. Standard Eurobarometer, 2021(94(Winter 2020-2021)). https://www.europa.eu/eurobarometer

Fomina, J., \& Kucharczyk, J. (2016). The specter haunting Europe: Populism and protest in Poland. Journal of Democracy, 27(4), 58-68. https://doi.org/10.1353/jod.2016.0062

Fukuyama, F. (1989). The end of history? The National Interest, 1989(16), 3-18.

Hochschild, A. R. (2018). Strangers in their own land: Anger and mourning on the American right. The New Press.

Kantar. (2021). Postrzeganie uchodźców w Polsce: Raport Kantar dla UNHCR. https://www.unhcr.org/pl /wp-content/uploads/sites/22/2021/02/Sondaz-UNHCR-2021-badanie-ogolnopolskie.pdf

Krastev, I. (2017). After Europe. University of Pennsylvania Press. https://doi.org/10.9783 19780812294262

Krzyżanowski, M. (2018). Discursive shifts in ethno-nationalist politics: On politicization and mediatization of the "refugee crisis" in Poland. Journal of Immigrant \& Refugee Studies, 16(1-2), 76-96. https://doi.org/10.1080/15562948.2017.1317897

Kubicki, P. (2020). Ruchy miejskie w Polsce. Wydawnictwo Nomos.

Lendvai-Bainton, N., \& Szelewa, D. (2020). Governing new authoritarianism: Populism, nationalism and radical welfare reforms in Hungary and Poland. Social Policy \& Administration, 55(4), 559-572. https://doi.org/10.1111/spol.12642

Leonard, M. (2005). Why Europe will run the 21st century. Fourth Estate.

Markowski, R. (2019). Creating authoritarian clientelism: Poland after 2015. Hague Journal on the Rule of Law, 11(1), 111-132. https://doi.org/10.1007/s40803-018-0082-5

Mazzoni, D., Albanesi, C., Ferreira, P. D., Opermann, S., Pavlopoulos, V., \& Cicognani, E. (2018). Cross-border mobility, European identity and participation among European adolescents and young adults. European Journal of Developmental Psychology, 15(3), 324-339. https://doi.org/10.1080/17405629.2017.1378089

Moes, J. (2009). CosmoPoles: A mixed-methods study on the European identity of higher-educated Polish youth. Studies in Ethnicity and Nationalism, 9(3), 429-451. https://doi.org/10.1111 /j.1754-9469.2009.01058.x

Mudde, C. (2004). The populist Zeitgeist. Government and Opposition, 39(4), 541-563. https://doi.org /10.1111/j.1477-7053.2004.00135.x

Netherlands - 2021 general election. (n.d.). POLITICO. https://www.politico.eu/europe-poll -of-polls/netherlands/ 
Pluciński, P. (2014). "Miasto to nie firma!" Dylematy i tożsamość polityczna miejskich ruchów społecznych we współczesnej Polsce. Przegląd Socjologiczny, 63(1), 137-170.

Résultats de l'élection présidentielle 2017. (n.d.). Ministère de l'Intérieur. https://www.interieur .gouv.fr/Elections/Les-resultats/Presidentielles/elecresult__presidentielle-2017/(path) /presidentielle-2017//FE.html

Rifkin, J. (2004). The European dream: How Europe's vision of the future is quietly eclipsing the American dream. Penguin.

Sadurski, W. (2019). Poland's constitutional breakdown. Oxford University Press. https://doi.org /10.1093/oso/9780198840503.001.0001

Stalker, P. (2002). Migration trends and migration policy in Europe. International Migration, 40(5), 151-179. https://doi.org/10.1111/1468-2435.00215

Triandafyllidou, A. (Ed.). (2016). Irregular migration in Europe: Myths and realities. Routledge. https://doi.org/10.4324/9781315589848

Van Mol, C. (2018). Becoming Europeans: The relationship between student exchanges in higher education, European citizenship and a sense of European identity. Innovation: The European Journal of Social Science Research, 31(4), 449-463. https://doi.org/10.1080 /13511610.2018.1495064

Yurchak, A. (2005). Everything was forever, until it was no more. Princeton University Press. https://doi.org/10.1515/9781400849109

\title{
Europejska opowieść o upadku (i przetrwaniu)
}

\begin{abstract}
Abstrakt
Artykuł jest recenzją książki After Europe autorstwa Ivana Krasteva. Skupia się na tezach autora na temat kryzysu, w którym znajduje się Europa, i omawia krytycznie historyczne paralele, zestawiające czasy współczesne z okresami dezintegracji w przeszłości. Recenzja dotyczy również analiz Krasteva na temat współczesnych wyzwań dla Europy, takich jak kryzys migracyjny lub narastanie populizmu. Autorka zakłada, że choć argumenty Krasteva są przekonujące i faktycznie można zaobserwować pewne niepokojące zjawiska, to istnieją także powody do ostrożnego optymizmu.
\end{abstract}

Słowa kluczowe: Europa; Unia Europejska; dezintegracja; tożsamość europejska; populizm

\section{Citation}

Sadecka, A. (2021). The European tale of downfall (and survival). Sprawy Narodowościowe: Seria nowa, 2021(53), Article 2525. https://doi.org/10.11649/sn.2525 